\title{
QUEEN'S
UNIVERSITY
BELFAST
}

\section{Recycling nutrients from anaerobic digestates for the cultivation of Phaeodactylum tricornutum: A feasibility study}

McDowell, D., Dick, J. TA., Eagling, L., Julius, M., Sheldrake, G. N., Theodoridou, K., \& Walsh, P. J. (2020). Recycling nutrients from anaerobic digestates for the cultivation of Phaeodactylum tricornutum: A feasibility study. Journal of Algal Research, 48, [101893]. https://doi.org/10.1016/j.algal.2020.101893

Published in:

Journal of Algal Research

Document Version:

Peer reviewed version

Queen's University Belfast - Research Portal:

Link to publication record in Queen's University Belfast Research Portal

\section{Publisher rights}

(c) 2020 Elsevier Ltd. All rights reserved.

This manuscript version is made available under the CC-BY-NC-ND 4.0 license http://creativecommons.org/licenses/by-nc-nd/4.0/,which permits distribution and reproduction for noncommercial purposes, provided the author and source are cited.

\section{General rights}

Copyright for the publications made accessible via the Queen's University Belfast Research Portal is retained by the author(s) and / or other copyright owners and it is a condition of accessing these publications that users recognise and abide by the legal requirements associated with these rights.

Take down policy

The Research Portal is Queen's institutional repository that provides access to Queen's research output. Every effort has been made to ensure that content in the Research Portal does not infringe any person's rights, or applicable UK laws. If you discover content in the Research Portal that you believe breaches copyright or violates any law, please contact openaccess@qub.ac.uk. 


\section{Recycling Nutrients from Anaerobic Digestates for the Cultivation of Phaeodactylum tricornutum: A Feasibility study.}

Daniel McDowell ${ }^{1}$, Jaimie Dick ${ }^{2}$, Lawrence Eagling ${ }^{2}$, Matt Julius ${ }^{3}$, Gary Sheldrake ${ }^{1}$, Katerina Theodoridou ${ }^{4}$, Pamela Walsh ${ }^{1}$

1School of Chemistry \& Chemical Engineering, Queen's University Belfast, ${ }^{2}$ The School of Biological Sciences, Queen's University, Belfast, ${ }^{3}$ Biological Sciences, St. Cloud State University, St. Cloud, MN, USA, ${ }^{4}$ The Institute of Global Food Security, Queen's University Belfast.

\section{Abstract (300 words)}

The valorisation of Anaerobic digestion (AD) waste streams into algal biomass to produce a protein alternative to soybeans could have significant commercial and environmental value. It has the benefit of alleviating the pressure of disposal of nutrient-rich digestate that is rich in $\mathrm{N}, \mathrm{P}$ and trace metals, while potentially reducing the cost of microalgae production. Currently, the use of soybean protein in animal feed has significant negative environmental issues and high carbon footprint associated with its use. This study investigates three types of AD to grow Phaeodactylum tricornutum Bohlin microalgae. The results found that the crude protein in all concentrations of $\mathrm{CW}$ and FW digestates were found to produce a significantly higher concentration of crude protein in comparison to the $\mathrm{F} / 2$ control. In addition, CW $1 \%$ and PW $1 \%$ formulations were found to have favourable fatty acid profiles, which has significant health benefits in the livestock industry. There was no significant difference in the total fatty acids (TFA) found in CW 1\% and PW 1\% digestates compared to the F/2 control, which was in the range of 243.4 to $269.4 \mathrm{mg} / \mathrm{g}$ (dry weight). The other formulations produced a significantly lower $(p<0.05)$ concentration of TFA compared to the control. CW $1 \%$ was found to be richer in omega-3, Eicosapentaenoic acid (EPA), compared to PW 1\%, however, no significant difference was found between the EPA concentration of CW $1 \%$ and the F/2 control. Overall, in terms of highest TFA and crude protein, CW 1\% digestate was found to perform the best out of all the digestates tested, and outperformed the F/2 control in terms of crude protein. The $P$. tricornutum grown in digestate was also found to bioaccumulate higher levels of calcium. $P$. tricornutum grown in $\mathrm{CW} 1 \%$ digestate could offer an alternative viable locally 
grown protein source for the animal feed industry, with the added advantage of being rich in EPA and calcium.

Keywords: Microalgae, bioremediation, fatty acids, proteins, anaerobic digestate Abbreviations: AD - Anaerobic Digestion, FAME - fatty acid methyl esters, ANOVA Analysis of Variance 


\section{Introduction}

In 2014 , over 2,503 million tonnes of food waste were generated from households and commercial businesses throughout the 28 member states of the EU [1]. In addition to food waste, intensive-livestock farming generates significant volumes of animal manure. For example, dairy farming in the EU generates close to 55 million tonnes of manure per annum [2]. Although waste management poses one of the most significant challenges for the future [1], the treatment of agriculture and food waste offers new opportunities for 'green' energy and nutrient recycling that would otherwise be generated from fossil fuels.

Anaerobic digestion (AD) technologies have been widely developed across the EU over the last few decades to manage and add value to waste from agriculture and food industries [3]. Whilst current policy incentives [4] have been successful in pushing the development of this technology in the generation of green energy, thus far the added value of nutrient recycling or recovery from $A D$ digestate has been largely overlooked. However, the market saturation of AD plants, dwindling government incentives toward 'green energy' and issues with disposal of nutrient-rich digestate is driving new research into adding value to the nutrient rich digestate produced by AD plants.

One area of research, which is gaining interest, is utilising digestate effluent as a nutrient source for growing microalgae. Microalgae contain many high value products including pigments [5], phycobillins [6], vitamins [7], carbohydrates [8,9], lipids [6] and proteins [10,11]. Microalgae require sources of nitrogen and phosphorus to enable cell function. All microalgae can use ammonium and most can use nitrate and nitrite for metabolism [12]. Anaerobic digestate is a rich source of nitrogen (in the form of nitrate, nitrate and ammonium), phosphorus and other trace micronutrients (e.g. calcium), therefore making it an ideal candidate as a nutrient source for microalgal production [13,14]. However, although increasing concentrations of nitrogen can increase protein concentrations in microalgal biomass, high 
concentrations (> 80 to $100 \mathrm{mg} \mathrm{NH}_{4}{ }^{+} \mathrm{L}^{-1}$ ) of ammonium can inhibit photosynthetic performance of the microalgae $[15,16]$. The inhibition threshold of ammonium is species dependent and currently undefined for most species. Previous studies have shown that it is possible to grow a range of microalgae species with waste media streams, including AD [17-23]. The chemical profile of the $A D$ digestate will affect the resultant chemical profile of microalgal biomass, often favouring protein synthesis as opposed to lipid and sugar synthesis [16], thus the material the $A D$ plant is fed could influence the downstream valorisation pathway of the microalgal biomass. A wide range of potential uses have been identified for microalgal biomass produced with $A D$ effluent, including animal feed, biofuel and high value co-products e.g. lutein, $\beta$ carotene and other pharmaceutical compounds [24-26] and bio-products [14,23,27,28]. However, its use as a nutrient source for algal growth still remains poorly studied to date [23].

Microalgal biomass has the potential to offer a viable and promising alternative to soybean [29] with an amino acid profile that is rich in essential amino acids [30]. Lamminen et al., recently reported that microalgae proteins are as good as soybean protein in the diets of lactating dairy cows [31] and swine [32]. Other studies have found that microalgal inclusion into livestock diet can improve growth rates and meat quality as highlighted in a recent review article by Madeira et al., [29]. Microalgal biomass also has the added benefit of producing nutritionally rich lipids, that contain omega-3 fatty acids such as EPA and docosahexaenoic acid (DHA), which can have significant animal health benefits when supplemented into their feed [33]. A recent study by Flaga et al., found that microalgae rich in DHA had a beneficial effect on the immune system of calves [34]. The inclusion of EPA from microalgae into the diets of hens has been reported to increase the omega- 3 content of the egg yolk, while reducing omega-6, which is of significant health benefit in human diets [35]. To date the main limitation to the use of microalgal biomass as an animal feed is the cost of production [36,37].

In this preliminary work we target a specific species, $P$. tricornutum known for high lipid production [38] and is also known as a good source of protein with up to $37 \%$ crude protein 
reported [39]. The animal feed industry is interested in both alternative rich sources of protein and nutritional rich fatty acids, such as EPA and DHA. Microalgal biomass that contains both would be of significant commercial value, providing the cost of microalgal production could be reduced. The valorisation of $A D$ waste streams to negate the cost and environmental impact of using expensive $\mathrm{N}$ and $\mathrm{P}$ could potentially reduce the cost of microalgae biomass. Currently, digestate used directly as biofertiliser is of lower commercial value [4], however, digestate used as a biofertiliser for microalgae growth could have significant commercial value, and reduce the current cost of microalgae production using synthetic nutrients. This is turn, could encourage animal feed companies to use it as an alternative to soybeans. This study investigates how effluent from three differently fed AD Plants affect its chemical profile with respect to the crude protein and fatty acids profile of the algae, with particular focus on omega3 fatty acids. The AD plants selected were (1) cow slurry and grass silage, (2) pre-consumer food waste and (3) pig slurry and grass silage. The nutrient composition of different slurries varies greatly in different animals [40], which results in different levels of nitrogen in the digestate. Mölle et al., reported cow slurry to be significant richer in nitrogen $(\mathrm{N})$, phosphorus (P) and potassium (K), (NPK) nutrients compared to pig slurry [41], whereas Waste and Resource Action Programme (WRAP) reported the opposite with pig slurry containing higher NPK nutrients. They also reported food waste to be the richer in $\mathrm{N}$ compared to pig and cow slurry, but significantly lower in P compared to them [42]. Diet fed to animal, geographical location, climate and other factors are likely to impact nutrient composition of the digestate [40], however, it is evident that there is a significant difference in the nutritional composition, and thus will provide a good range of nutrient variation to test algal growth.

The first objective was to evaluate the potential of using $A D$ digestate (nutrients) as a biofertiliser for microalgal growth and assess its bioremediation capabilities with respect to the metal ions present in the digestate. The second objective was to study the nutritional chemical profile of the resultant algal biomass with respect to their fatty acid profiles and percentage of 
crude protein, to assess their suitability as an animal feed in terms of the resultant chemical profiles.

\section{Materials and Methods}

\subsection{Experimental Design}

Digestate samples were taken from each AD Plant on the same date for this experiment. Prior to this experiment a 12-month screening study was performed to assess the nutrient profile of the effluent from each plant, to check the yearly availability of nutrients. The results found the nutrient profiles to be relatively consistent through the year. In this experiment, digestate from three different AD Plants: $(\mathrm{CW})$ Cow Waste $=$ cow slurry and grass, $(\mathrm{FW})$ Food Waste $=$ preconsumer food waste, (PW) Pig Waste = pig slurry, grass/maize silage was tested. To grow the microalgae, three concentrations $(1 \%, 3 \%$ and $6 \% \mathrm{v} / \mathrm{v})$ of each digestate were diluted in sea water. A control group of $P$. tricornutum was also grown with industry standard synthetic $\mathrm{F} / 2$ medium. The ten different groups were grown in triplicate, resulting in a total of thirty $5 \mathrm{~L}$ photobioreactors being used in the experiment. Fluorescent white light (light radiation: 170 $\left.\mu \mathrm{mol} \mathrm{m}^{-2} \mathrm{~s}^{-1}\right)$ strips were used as the light source. A randomised block design was used where each flask was given a number and then randomly assigned to a space on the shelf. This enabled subsequent analyses to remove light levels or position as a factor. The air temperature of the microalgae hatchery was recorded daily (using a standard aquarium thermometer) to be $20\left( \pm 1^{\circ} \mathrm{C}\right)$ throughout the experiment. An airline was added to each flask to ensure adequate mixing of the cultures.

\subsubsection{Media Preparation}

Before the liquid digestates were added to the UV filtered seawater they were centrifuged at $4000 \mathrm{rpm}$ for 10 minutes to remove any solids. The digestate media solutions were prepared by adding $1 \%, 3 \%$ or $6 \% \mathrm{v} / \mathrm{v}$ liquid digestate effluent to sea water to make up $3.2 \mathrm{~L}$ of solution. $50 \mathrm{~g}$ of activated carbon (Sigma-Aldrich 05105 ) was then added to this solution and stirred for 20 mins with a magnetic stirrer bar. The solution was then passed through a Buchner funnel, 
which contained a sheet of filter paper (Fisherbrand 11576873) on top of which diatomaceous earth (ACROS, 123380010) was packed to a depth of $3 \mathrm{~cm}$. The solution was passed through the filter and collected. This process was repeated until the medium was transparent in appearance, the higher concentrations of digestate required more repetitions. $3 \mathrm{~L}$ of $\mathrm{AD}$ medium was then placed in clean $5 \mathrm{~L}$ conical flasks. Each flask was supplemented with $3 \mathrm{~mL}$ of metasilicate solution (Varicon Aqua Solution) required by $P$. tricornutum for forming silicate frustules, $\mathrm{pH}$ balanced to 8.2 and then autoclaved at $121{ }^{\circ} \mathrm{C}$ for 15 minutes. The process of autoclaving was used to remove any pathogens, which may have been present. Although, this system is suitable for laboratory scale work, for scaled up, a pasteurisation segment would need to be added to the AD system to remove pathogens. To comply with PAS110 regulations in the UK, may AD plants have a pasteurisation system in place. The flasks were left to cool overnight before adding the $P$. tricornutum inoculum.

\subsubsection{Algae Cultivation}

Cultures of $P$. tricornutum were inoculated from stock cultures held at Queen's Marine Laboratory (QML) in Portaferry, Co. Down, Northern Ireland. All of these cultures were initially grown up from a pure culture provided by the Scottish Association for Marine Science (SAMS) Culture Collection of Algae and Protozoa (CCAP 1052/1B). In preparation for this study, cultures of $P$. tricornutum were grown in three $10 \mathrm{~L}$ carboys, each containing $6.5 \mathrm{~L}$ of algae culture in synthetic F/2 commercial media (See supplementary Table 1 for composition). After reaching their critical abundance, the flasks were homogenised by mixing. Samples were then taken for cell counting to determine the correct concentration of culture to inoculate the flasks.

\subsubsection{Monitoring Algae Growth}

Algal cell abundance was monitored throughout the experimental period using two methods for accuracy. Cells were counted manually using a Neubauer chamber and an inverted 
microscope (Leica DM IRB) and chlorophyll absorbance as a proxy for cell concentration was performed using a spectrophotometer (Thermo Spectronic Helios B). Samples of culture media were taken from each flask three times per week for analysis for the duration of the experiment to monitor growth. The manual counting method required $10 \mathrm{ml}$ of culture mixed with $9 \mathrm{~mL}$ of seawater and $1 \mathrm{~mL}$ of Lugol's iodine. The chlorophyll absorbance method used a cuvette filled directly with cell culture. Cuvette samples were analysed within half an hour of sampling in the spectrophotometer which was calibrated using distilled water prior to running the samples. Media samples were frozen after sampling and manual cell counts were carried out, after defrosting, a maximum of two weeks after samples were frozen $\left(-20^{\circ} \mathrm{C}\right)$. Three replicates were taken from each sample to ensure reliable counts and the average used to represent the number of cells per $\mathrm{mL}$ for each experimental variable.

\subsection{Chemical Analysis}

\subsubsection{Auto Analyser Analysis of media}

Samples were taken for nutrient analysis at the same time points used for cell count estimates. An auto-analyser (Bran Luebbe AA3) was used to measure ammonia, nitrate, nitrite and phosphate levels. Samples were centrifuged to remove any particulates from the solution, then frozen at $-20^{\circ} \mathrm{C}$ and then run simultaneously on the auto-analyser. The instrument was calibrated using two runs of each sample at different dilutions, firstly to identify the level of ammonia (1 part per 5000 dilution) and then for nitrite, nitrate and phosphate (1 part per 100 dilution) analysis.

\subsubsection{Elemental analysis - Media and Microalgae}

Inductively coupled plasma optical emission spectrometry (ICP-OES) analyses were run by the QUB ASEP facility. Approximately $0.1 \mathrm{~g}$ of sample (either media or microalgae) was dissolved in $10 \mathrm{~mL}$ of concentrated nitric acid and microwave digested with a CEM Discover 
Explorer microwave reactor (temperature: $200^{\circ} \mathrm{C}$, ramp time: 5 mins, hold time: 5 mins, pressure: 350 psi, power: $300 \mathrm{~W}$ ). The sample was then heated on a hotplate, cooled and diluted to $25 \mathrm{~mL}$ with deionised water. For elemental analysis, an Agilent 5100 ICP-OES instrument was used under the following conditions: replicate injections - 3 , injection volume $1 \mathrm{~mL}$, pump speed - $12 \mathrm{rpm}$, nebulizer flow - $0.70 \mathrm{~L} / \mathrm{min}$, plasma flow - $12.0 \mathrm{~L} / \mathrm{min}$, stabilization time: 15 secs, auxiliary flow $-1.00 \mathrm{~L} / \mathrm{min}$.

\subsubsection{Fatty Acid Derivatisation}

A one-step derivatisation technique from the literature was used to determine the fatty acid profile in the algae [43], with a small modification. Instead of adding a fatty acid methyl ester internal standard after the derivatisation process, in this study pentadecanoic acid was added as the internal standard before the derivatisation process. This was used to confirm that each microalgae sample had been completely derivatised. Briefly, the one-step derivatisation method involved weighing approximately $0.1 \mathrm{~g}$ of freeze-dried microalgae into a $30 \mathrm{~mL}$ screw top Pyrex vial. To this, $2 \mathrm{~mL}$ of toluene spiked with $400 \mathrm{mg} / \mathrm{L}$ internal standard (pentadecanoic acid) was added, followed by $3 \mathrm{~mL}$ of $5 \% \mathrm{HCl}$ in methanol. The head space was filled with nitrogen and the cap tightly closed. The vials were put in a water bath for 2 hours at $70^{\circ} \mathrm{C}$, after which they were cooled to room temperature. Once cool, $4 \mathrm{~mL}$ of $6 \%$ potassium carbonate in water was added. The solution was then transferred to a $15 \mathrm{~mL}$ centrifuge tube and vortexed for 5 minutes, after which it was centrifuged for 10 minutes at $4000 \mathrm{rpm}$. The organic top layer was removed with a glass Pasteur pipette and put into Gas Chromatography (GC) vials ready for analysis. For each microalgae sample three derivatisations were performed on each replicate flask.

\subsubsection{Fatty acid identification with Gas Chromatography}


The fatty acid methyl esters (FAME) were analysed on an Aglient 6890N Gas Chromatograph with Flame lonisation Detector with a Phenomenex 7HM-G007-17 ZB-WAX (30 m x $0.32 \mathrm{~mm}$ $x 0.5 \mu \mathrm{m}$ ) capillary column. The sample front inlet temperature was set to $250^{\circ} \mathrm{C}$ and the split ratio was $1: 50$. The oven temperature was set to $70^{\circ} \mathrm{C}$ for 1 minute, then increased to $200^{\circ} \mathrm{C}$ at a rate of $35^{\circ} \mathrm{C} / \mathrm{min}$, followed by $5^{\circ} \mathrm{C} / \mathrm{min}$ up to $260^{\circ} \mathrm{C}$. Peaks were identified by comparing retention times to a Supelco 37 component FAME mix (Sigma), along with a stearidonic acid methyl ester standard (Cayman Chemical Company) which was not present in the FAME mix.

\subsubsection{Quantification of fatty acids}

Fatty acids were quantified using the equation below [44], which was modified to include the derivatisation rate. The derivatisation rate was calculated by comparing the peak area of an internal standard (pentadecanoic acid) against an external standard (methyl pentadecanoate). The response factor was calculated using the areas of the FAME mix peaks and the concentrations stated on the corresponding data sheet, see equation 1.

$$
\begin{aligned}
& \text { FA content }\left(\frac{m g}{g}\right) \\
& \qquad=I S \text { added }\left(\frac{m g}{\text { sample }}\right) \times \frac{\left[\frac{\text { Area of Unknown Fame }}{\text { Area of IS x Response Factor x Derivitisation Rate }}\right]}{\text { Mass of Algae }(g)}
\end{aligned}
$$

\subsubsection{Crude Protein}

Carbon, hydrogen, nitrogen, sulphur (CHNS) elemental analysis was run by QUB Analytical Services and Environmental Projects (ASEP) facility. The samples were combusted in a Perkin Elmer Series 2 CHNS Analyzer 2400. Blanks and standards (Cystine A) were used to calibrate the instrument. Approximately $1-2 \mathrm{mg}$ of freeze-dried microalgae was used for this 
analysis. The crude protein was calculated by multiplying the percentage of nitrogen by 4.78 [45].

\subsection{Statistical Analysis}

All Statistical analyses were performed using SPSS (IBM SPSS Statistics, version 24, NY). A Fisher's way ANOVA was used to compare culture values for crude protein, biomass produced, and multiple fatty acid parameters. In each case, data appeared to be normally distributed and appeared not to violate other assumptions required for one-way ANOVA comparison. The Ryan-Einot-Gabriel-Welsh-F post-hoc analysis was used to compared treatments for each of the biochemical measurements obtained from the replicate cultures. For all ANOVA comparisons a critical value of $\alpha=0.05$ was used to test the null hypothesis, $\mathrm{H}_{\mathrm{O}}$ $=$ all culture treatments responded identically. Cell count data for cultures on day 16 were compared using a Welch's ANOVA with a Games-Howell post hoc test. These tests were selected over the classic Fisher's ANOVA and Tukey's post hoc test because variances in the data set were not equal (Levene's homogeneity of variance $p=0.0337$ ). A critical value of $\alpha$ $=0.05$ was used to test the null hypothesis, $\mathrm{H}_{\mathrm{O}}=$ all culture treatments produced the same cells numbers. A one-sided Student's t-test of means was used to compare differences in nitrites, nitrates, ammonium and phosphorus concentrations of pure effluent media and media post algal harvest. A critical value of $\alpha=0.05$ was used to test the null hypothesis, $H_{\circ}=$ no reduction in nutrients (nitrogen or phosphorus) occurred during cell growth. In each case, data appeared to be normally distributed and appeared not to violate other assumptions required for Student's t-test comparison. 


\section{Results and Discussion}

\subsection{Digestate Characterisation}

\subsubsection{Elemental Chemical Profile of stock digestates}

The element data for stock digestate used in the media preparation for the different growth conditions is shown in Fig 1 . The results show a relatively similar metal composition, in that $\mathrm{K}$, $\mathrm{Na}$ and $\mathrm{P}$ were the predominant elements. However, significant variation in concentrations of metals was observed within the same type of metal. The highest $\mathrm{K}$ concentration was observed in PW digestate, which was found to be $5 \mathrm{~kg} /$ tonne, followed by $\mathrm{CW}$ digestate, which was slightly lower at just over $4 \mathrm{~kg} / \mathrm{tonne}$, which supports the trends observed by Mölle et al., [41]. FW digestate was found to contain the lowest concentration $(\approx 2 \mathrm{~kg} /$ tonne $)$ of $\mathrm{K}$. The opposite trend was observed in FW digestate in terms of the $\mathrm{P}$ concentration, which was found to be the most elevated at $\approx 0.35 \mathrm{~kg} /$ tonne, followed by CW $(\approx 0.18 \mathrm{~kg} /$ tonne $)$, then $\mathrm{PW}(\approx$ $0.14 \mathrm{~kg} /$ tonne) digestate. This is the opposite trend to the results reported by WRAP, who reported FW digestate to have the lowest concentration of $P$ [42]. The most likely cause for variation in the nutrient composition between our results and WRAP are factors such as animal diet and geographical located as cited by Risberg et al [40]. 


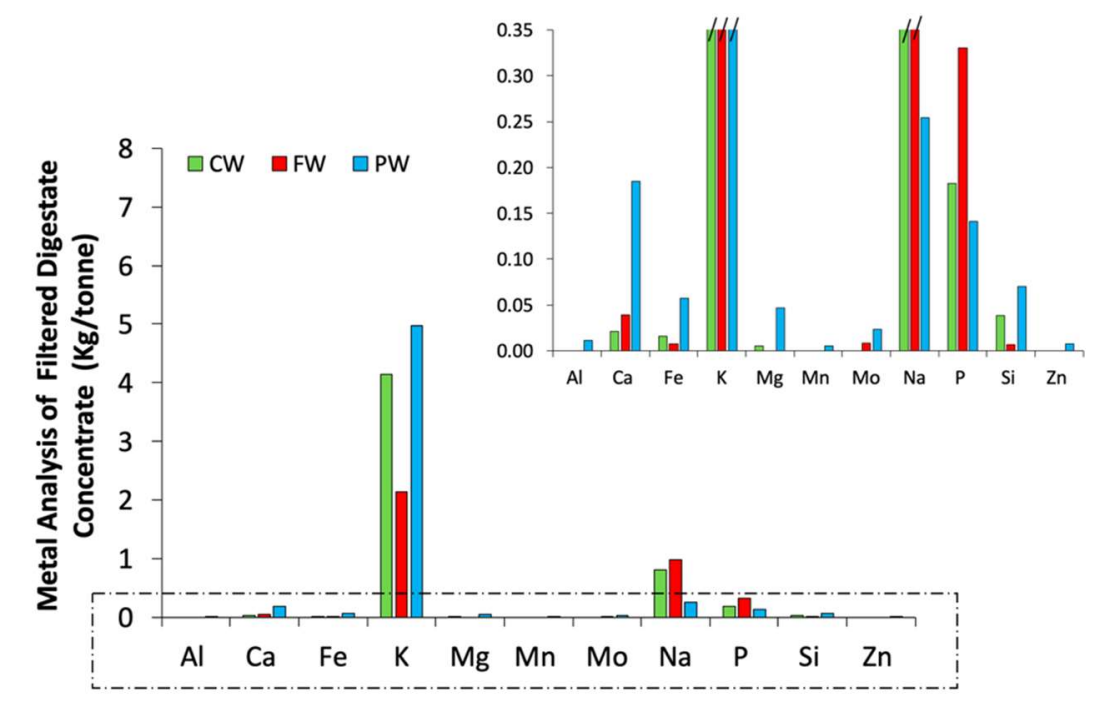

Figure 1. Representative metal profile of filtered stock solution from each AD plant used to prepare media for algae culture experiment. Units (kg/tonne).

The total inorganic nitrogen content of media solutions before microalgal inoculation was highly dependent on the concentration of digestate and the source of digestate (Fig 2a). CW and FW contained vastly more total inorganic nitrogen than PW digestate. These differences are attributable to the different feedstocks for each of the three anaerobic digesters. The levels of total inorganic nitrogen increased with the concentration of digestate within the $A D$ treatments as expected. The levels of total inorganic nitrogen were significantly reduced in CW $1 \%$ from $14.93( \pm 1.40)$ to $9.48( \pm 1.88) \mathrm{mgL}^{-1}(p=0.03)$, CW $3 \%$ from $49.92( \pm 3.77)$ to $17.09( \pm 0.07) \mathrm{mgL}^{-1}(p \geq 0.001)$, CW $6 \%$ from $145.26( \pm 0.24)$ to $66.82( \pm 0.09) \mathrm{mgL}^{-1}(p=0.014)$ treatments and FW $3 \%$ from $59.74( \pm 1.84)$ to $10.23( \pm 5.83) \mathrm{mgL}^{-1}(p \geq 0.001)$, FW $6 \%$ from $144.40( \pm 0.02)$ to $43.31( \pm 0.07) \mathrm{mgL}^{-1}(p=0.008)$, at the end of the microalgae growth period. The inorganic nitrogen reduction ranged from $36 \%$ in $\mathrm{CW} 1 \%$ to $82 \%$ in $\mathrm{FW} 3 \%$, which is comparable to previous research [46]. This reduction was significant in five out of ten conditions tested (Fig. 2a). This is a substantial reduction in total inorganic nitrogen and evidence of the bioremediation capacity of $P$. tricornutum in utilizing nitrogen from its surrounding environment. When looking at the breakdown of the different fractions (Fig 2bd), the digestate was found to be richest in ammonium, which is comparable to previous 
literature [47]. Several studies have reported that high concentrations of ammonium in digestate can inhibit photosynthetic performance of the microalgae $[15,16,48]$. The concentration of ammonium, as with the total inorganic nitrogen varies depending on feedstock fed to the digestor. Digestates $\mathrm{CW}$ and FW at 3 and $6 \%$ concentrations of effluent was found to have similar concentrations of ammonium that increased from approximately 4 $-7 \mathrm{mg} / \mathrm{L}$ to just below $125 \mathrm{mg} / \mathrm{L}$ as shown in Fig $2 \mathrm{~d}$.
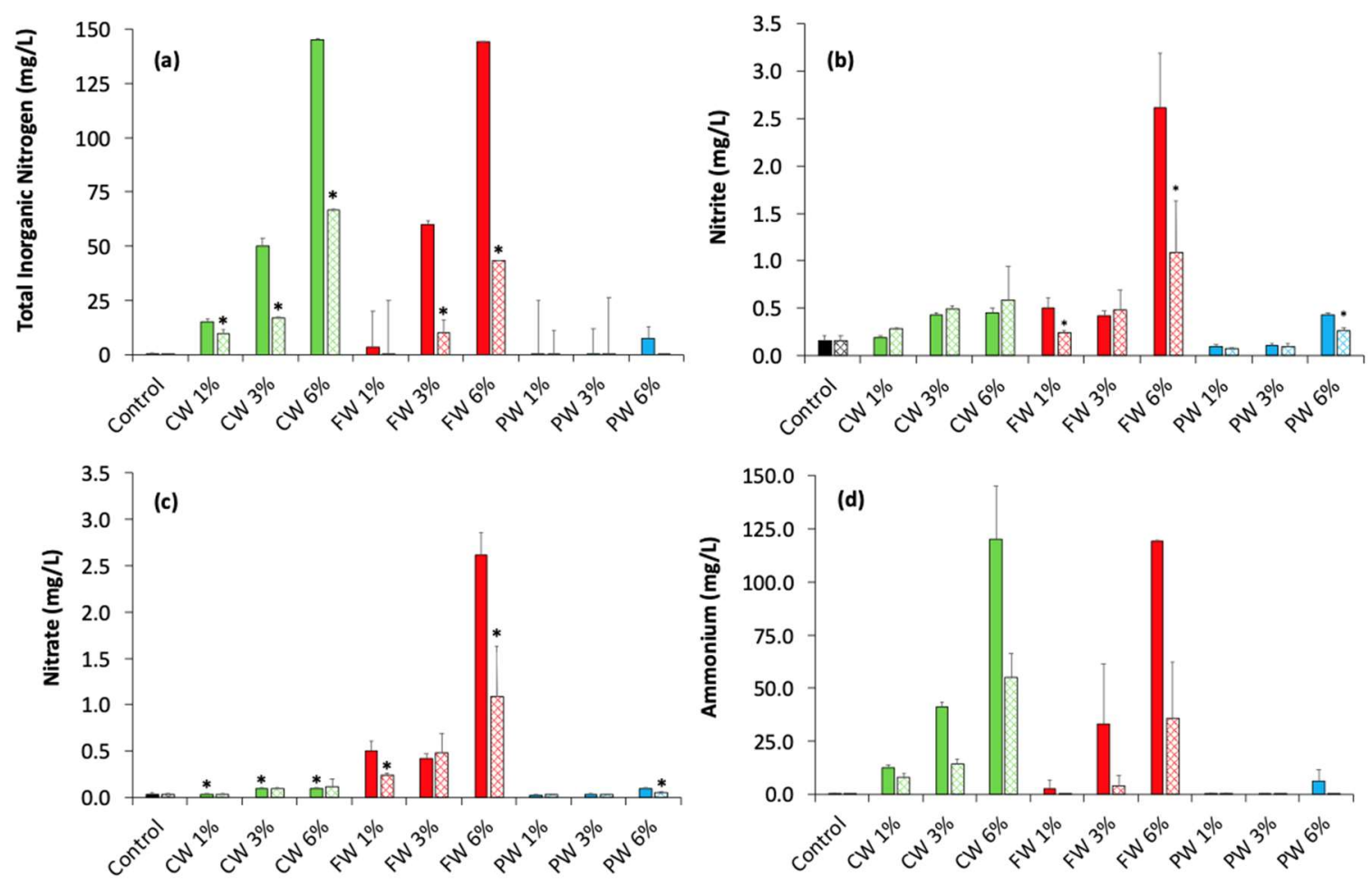

Figure 2. Nitrogen Sources in AD (a) Nitrite (b) Nitrate (c) Ammonium and (d) Total inorganic nitrogen concentration of media before inoculation (solid fill) and after microalgae harvest (cross hatch). Error bars show the mean +/- standard deviation (3 bioreactor replicates with 3 readings per bioreactor). ${ }^{*}$ denotes a significant decrease in concentration by Student $t$-test at $p<0.05$.

\subsection{Microalgae Growth}

All tested variations of digestate media provided sufficient nutrients for $P$. tricornutum to grow at comparatively similar or higher rates than the F/2 commercial control (Fig. 
1a-i). At lower concentrations (1 and $3 \%$ ) all three AD treatments had no lag adaptation phase between the point of inoculation and 5 days in culture. At higher concentrations of effluent $(6 \%)$, however, a lag time in growth was observed during the same period. The most prevalent lag was found in FW followed by CW and PW, which would suggest either the macronutrients or nitrogen concentration at this level is slowing down or having an inhibitory effect on the cell growth. Two factors which influence lag phase development in cultures are inoculum density and cell adaptation to nutrients. Lag phases were seen in higher nutrient concentration cultures and not in lower nutrient concentration cultures with all culture receiving the same inoculum concentration. This suggests the presence or absence of lag phase was related to cell adaptation to nutrient concentrations. Similar trends were observed in other studies, whereby the algae was found to quickly adapt to the nutrient profile of $A D$ effluent media without a lag period $[17,22]$. There were significant differences in the culture treatments identified by the Welch's ANOVA $\left(p=1.54 \times 10^{-4}\right)$. The GamesHowell post hoc test (Table 1), however, indicated that the control cultures never outgrew the $A D$ effluent treatments at any concentration. Only the FW $3 \%$ differed significantly from the control culture with a greater growth rate. The algal cell abundance was also recorded using chlorophyll absorbance for accuracy. The growth curves observed (Fig. 3d-f) followed the same trend as the cell count (Fig. 3a-c), with the exception of $3 \% \mathrm{PW}$ at day 12 , which decreased in the cell count but increased in the chlorophyll data. The specific growth rate was found to be inversely proportional to the number of days in culture at 1 and $3 \%$ concentrations of effluent. At $6 \%$ the specific growth rate between 5 and 9 days remained stationary for the FW treatment, before exponentially decreasing at day 9 following the same trend as the other treatments. Previous studies also reported an inverse trend with respect to specific 
growth rate in relation to the number of days in culture when growing algae in $A D$ effluent [13] and wastewaters [30] supporting these findings. Viewing the data overall indicates that higher nutrient concentrations lead to longer exponential growth and higher accumulated biomass. The exponential phase of the F/2 control culture peaked after 12 days. At this stage, nutrients in the media are depleted and the culture moves into its stationary phase. The microalgae in digestate media took longer to reach the stationary phase of growth. Biomass accumulation on day of harvest was significantly higher in these cultures grown on digestate media in comparison to F/2 media control. The same trend was observed in the PW treatment at $1 \%$ concentration, whereas the other treatments at this concentration and higher continued in their exponential growth phase. The time to reach the stationary phase varied, within a 14-day period, from 12 to 26 days after inoculation.

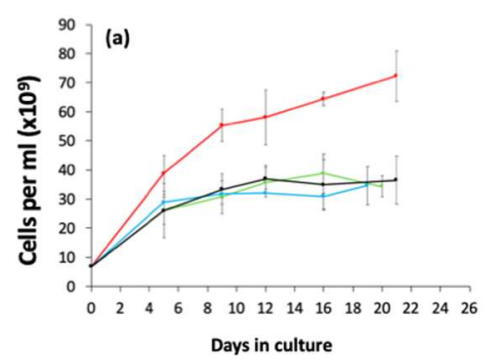
$-\mathrm{CW}-\mathrm{FW}-\mathrm{PW}-\mathrm{F} / 2$
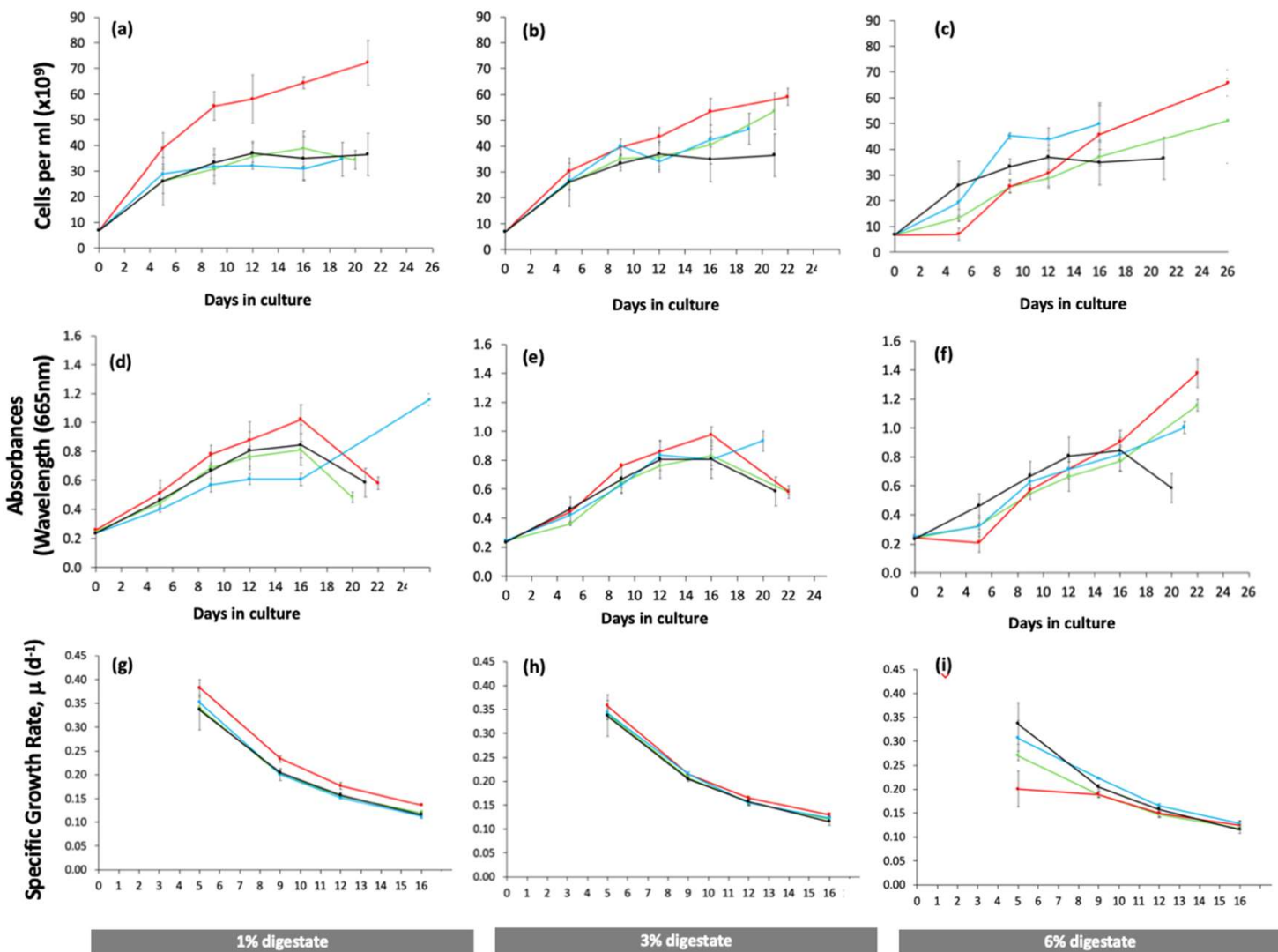
Figure 3. Cells per $\mathrm{mL}$ of microalgae in media of digestate concentrations a.) $1 \%$ b.) $3 \% \mathrm{c}$.) $6 \%$. Chlorophyll content of microalgae in media d.) $1 \%$ e.) $3 \%$ f.) $6 \%$. Specific growth rate at g.) 1 $\%$ h.) $3 \%$ i.) $6 \%$. Growth data is presented as mean $+/-$ standard deviation (3 bioreactors replicates with 3 counts/readings per bioreactor).

\begin{tabular}{|c|c|c|c|c|c|c|c|c|c|c|}
\hline Treatments & CW 1\% & FW 1\% & PW 1\% & CW 3\% & FW 3\% & PW 3\% & CW 6\% & FW 6\% & PW 6\% & Control \\
\hline CW 1\% & & 1.000 & 1.000 & $\mathbf{0 . 0 0 4}$ & 0.236 & 0.939 & 0.898 & 0.999 & 0.571 & 0.999 \\
\hline FW 1\% & 0.502 & & 1.000 & $\mathbf{0 . 0 0 9}$ & 0.401 & 0.992 & 0.729 & 1.000 & 0.780 & 0.983 \\
\hline PW 1\% & 0.426 & 0.928 & & $\mathbf{0 . 0 0 2}$ & 0.140 & 0.827 & 0.973 & 0.988 & 0.396 & 1.000 \\
\hline CW 3\% & 6.700 & 6.198 & 7.126 & & 0.589 & 0.063 & $\mathbf{0 . 0 0 0}$ & $\mathbf{0 . 0 1 8}$ & 0.247 & $\mathbf{0 . 0 0 1}$ \\
\hline FW 3\% & 3.827 & 3.325 & 4.252 & 2.874 & & 0.915 & $\mathbf{0 . 0 1 4}$ & 0.609 & 1.000 & 0.064 \\
\hline PW 3\% & 1.855 & 1.353 & 2.281 & 4.845 & 1.972 & & 0.217 & 1.000 & 0.999 & 0.596 \\
\hline CW 6\% & 2.043 & 2.544 & 1.617 & 8.743 & 5.869 & 3.897 & & 0.517 & 0.054 & 0.999 \\
\hline FW 6\% & 0.998 & 0.497 & 1.424 & 5.702 & 2.828 & 0.857 & 3.041 & & 0.928 & 0.908 \\
\hline PW 6\% & 2.914 & 2.412 & 3.340 & 3.786 & 0.912 & 1.059 & 4.957 & 1.916 & 0.212 \\
\hline Control & 1.004 & 1.505 & 0.578 & 7.704 & 4.830 & 2.858 & 1.039 & 2.002 & 3.918 \\
\hline
\end{tabular}

Table 1: Welch's One-way ANOVA for day 16 algal cell number in each treatment at different concentrations with a Games-Howell Post hoc Test based on cell number data in Fig 3 (a to $c$ ). Bold numbers indicate significance $(p<0.05)$.

\subsection{Media Nutrient Loss}

The total inorganic nitrogen content of media solutions before microalgal inoculation was highly dependent on the concentration of digestate and the source of digestate (Fig 4a). CW and FW contained vastly more total inorganic nitrogen than PW digestate. These differences are attributable to the different feedstocks for each of the three anaerobic digesters. The levels of total inorganic nitrogen increased with the concentration of digestate within the $A D$ treatments as expected. The levels of total inorganic nitrogen were significantly reduced in CW $1 \%(p=0.03)$, CW $3 \%(p \geq 0.001)$, CW $6 \%(p=0.014)$ treatments and FW $3 \%(p \geq 0.001)$, FW $6 \%(p=0.008)$, at the end of the microalgae growth period. The inorganic nitrogen reduction ranged from $36 \%$ in CW $1 \%$ to $82 \%$ in FW $3 \%$, which is comparable to previous research [46]. This reduction was significant in five out of ten conditions tested (Fig. 4a). This is a substantial reduction in total inorganic nitrogen and evidence of the bioremediation 
capacity of $P$. tricornutum in utilizing nitrogen from its surrounding environment. When looking at the breakdown of the different fractions (Fig $4 b-d$ ), the digestate was found to be richest in ammonium, which is comparable to previous literature [47]. Several studies have reported that high concentrations of ammonium in digestate can inhibit photosynthetic performance of the microalgae $[15,16,48]$. The concentration of ammonium, as with the total inorganic nitrogen varies depending on feedstock fed to the digestor. Digestates CW and FW at 3 and $6 \%$ concentrations of effluent was found to have similar concentrations of ammonium that increased from approximately 4 $7 \mathrm{mg} / \mathrm{L}$ to just below $125 \mathrm{mg} / \mathrm{L}$ as shown in Fig $4 \mathrm{~d}$. At all three ammonium concentrations a significant reduction in ammonium was observed at the end of the growth period. It also shows that $P$. tricornutum can proliferate within a large range of total inorganic nitrogen levels, with high concentrations of ammonium (Fig 4d) as shown by the harvested biomass data (Table 2) and the growth data (Fig.3). González et al., observed similar findings when growing microalgae on piggery wastewaters with high concentrations of ammonium. The study reported daily adjustments of the $\mathrm{pH}$ to 7 was required to prevent algal inhibition from high concentrations of ammonium [50]. The $\mathrm{pH}$ was monitored regularly and adjusted to $\mathrm{pH} 8.2$ every two days, which was slightly more alkaline to González et al., who maintained their $\mathrm{pH}$ at natural. In microalgae growth, although ammonium can inhibit growth, it is the preferred $\mathrm{N}$ source, due to its reduced state and energetically favourable assimilation. Ammonium has been reported to have a negative effect on nitrate assimilation [51], which may account for the increase in nitrate after growth opposed to the decrease.

The removal of phosphorus from anaerobic digestate media has been shown to be effective with a range of microalgal species [18], although there is little data available 
for $P$. tricornutum. It has also been shown that, when in nutrient rich environments, microalgae can uptake higher levels of phosphorus than required for growth alone [52]. In this study, the initial concentration of phosphorus within the various media, generally increased with digestate concentration (apart from FW $3 \%$ ). PW media had comparable concentrations of phosphorus to $\mathrm{CW}$ media and FW media, which is in contrast to the total inorganic nitrogen figures, which showed that PW media had a much lower abundance than $\mathrm{CW}$ media or FW media. CW media contained the lowest levels of phosphorus within the digestate medias, while the control (F/2) also exhibited comparatively low levels of phosphorus. After microalgal growth period, the level of phosphorus remaining in the media was significantly reduced or completely removed (Fig. 4) in all media $(p=<0.001)$ apart from PW 3\% $(p=0.053)$. Microalgae are known to accumulate excess phosphorous when available, storing it in cell reserves for periods of prolonged growth in the absence of available phosphorus [53]. This could point towards the possibility of phosphorus recovery from anaerobic digestate with microalgae which, once harvested, would have many storage advantages over anaerobic digestate effluent. 


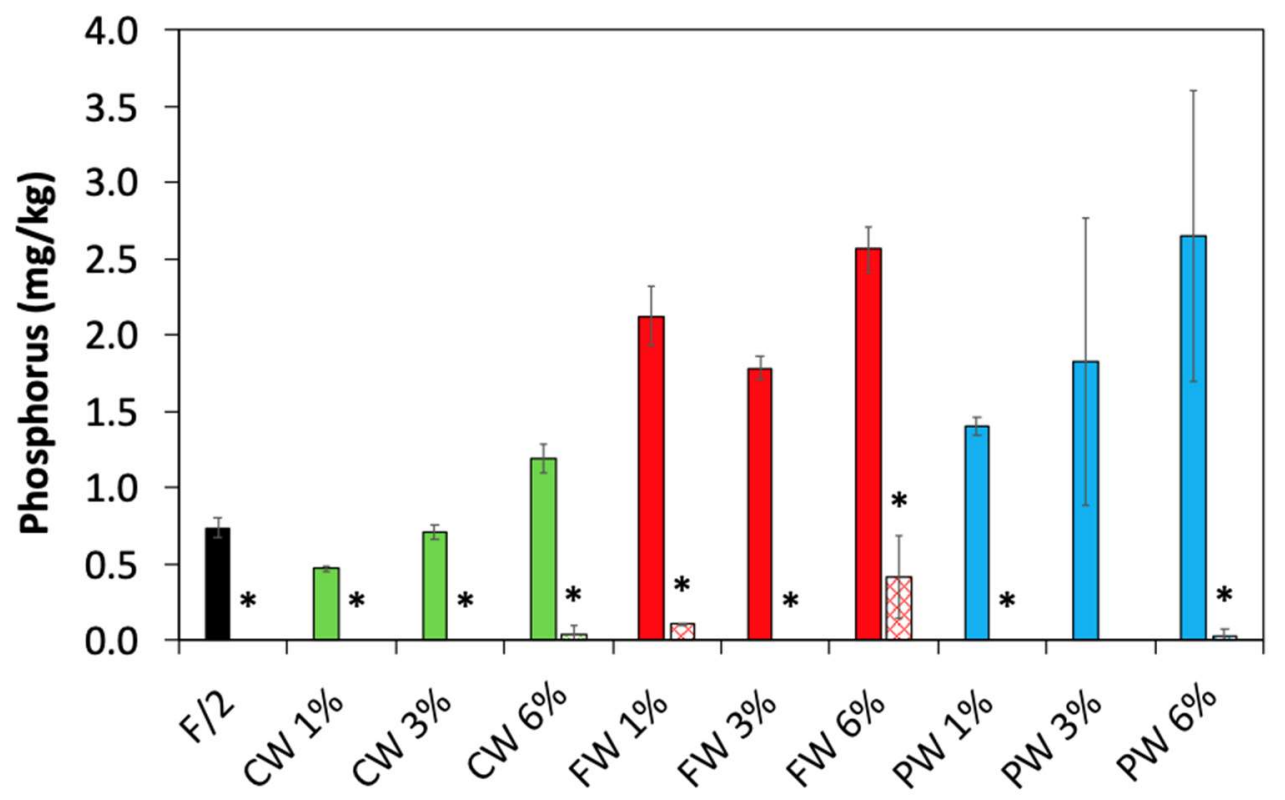

Figure 4. Phosphorus concentration of media before inoculation (solid fill) and after microalgae harvest (cross hatch). Error bars show the mean $+/-$ standard deviation ( 3 bioreactor replicates with 3 readings per bioreactor). ${ }^{*}$ denotes a significant decrease in concentration by Student $t-$ test at $p<0.05$.

\subsection{Microalgae Composition}

\subsubsection{Fatty Acids}

With regards to the proportion of lipids accumulated, the results presented here are similar to the findings of Wu and co-workers [54] who grew six $P$. tricornutum strains in F/2 medium, recording a total lipid dry weight between $15.91 \%-30.75 \%$. The type of fatty acids found within $P$. tricornutum ranged from 47-51 \% monounsaturated, 29$38 \%$ saturated and $14-23 \%$ polyunsaturated. Regarding the quantity of specific fatty acids, the most abundant were $\mathrm{C} 16: 1, \mathrm{C} 16: 0$ and $\mathrm{C} 20: 5 \mathrm{n} 3$ respectively (Table. 2). The polyunsaturated fatty acid C20:5n3 also known as eicosapentaenoic acid (EPA), is an omega-3 polyunsaturated fatty acid. This specific type of fatty acid has been shown to have many health benefits in humans including cognitive function, foetal development, weight management and cardiovascular health [55]. The highest levels of EPA were 
found to be in microalgae grown in medium CW $1 \%$, which contained $30 \mathrm{mg} / \mathrm{g}$. Harvesting microalgae in this way could help tackle the sustainability issues surrounding EPA sourced from marine fish [56].

The general trend with the digestate media was that the lower levels of digestate concentrations, produced microalgae which had higher quantities of fatty acids per gram (dry weight) of sample (Table 2). The microalgae grown in CW $1 \%$, pig farm 1 $\%$ and the control had the highest levels of total fatty acids while the microalgae grown in CW $6 \%$, FW $6 \%$ and PW $6 \%$ had the lowest levels. It has been previously documented that marine microalgae, including $P$. tricornutum [57], store lipids during periods of nutrient limited growth [58]. This explains why microalgae grown in food waste $1 \%$ had significantly less total fatty acids than microalgae grown in digestate cow farm $1 \%$ or pig farm $1 \%$. FW digestate had relatively high levels of both total nitrogen and phosphorus, meaning that, even at $1 \%$ concentration, the nutrient levels were not low enough to induce high levels of lipid storage. If microalgal lipids are to be the targeted compounds after harvesting, then nitrogen stripping would be required prior to growth.

It should be noted that although FW $1 \%$ produced low levels of total fatty acids, it produced significantly more total biomass than CW $1 \%$ or PW $1 \%$. Therefore, when converted to amount of fatty acids harvested per litre of medium, FW $1 \%$ had the highest value $(95.6 \mathrm{mg} / \mathrm{L})$ of all the digestate-grown microalgae. This highlights that when screening microalgae for real-world applications, the amount of fatty acids per litre of medium is often more helpful than amount of fatty acid per gram of algae. The microalgae grown in the F/2 medium (control) recorded the highest value of $112 \mathrm{mg} / \mathrm{L}$, 
although this was not statistically larger than the top performing digestate fed microalgae medium. This demonstrates that $P$. tricornutum can be grown with anaerobic digestate as a nutrient source and produce biomass with a comparable or even more favourable fatty acid and crude protein quantity to a control grown in F/2 medium.

\begin{tabular}{|c|c|c|c|c|c|c|c|c|c|c|}
\hline $\begin{array}{l}\text { FA in Microalgae } \\
\text { ( } \mathrm{mg} / \mathrm{g} \text { dry wt) }\end{array}$ & Control & CW 1\% & CW 3\% & CW $6 \%$ & FW 1\% & FW 3\% & FW 6\% & PW 1\% & PW 3\% & PW 6\% \\
\hline $\mathrm{c} 14: 0$ & $11.2 \pm 1.1$ & $11.1 \pm 0.9$ & $6.5 \pm 0.5$ & $4.9 \pm 0.1$ & $8.4 \pm 0.4$ & $5.4 \pm 0.2$ & $5.0 \pm 0.9$ & $12.7 \pm 0.9$ & $8.1 \pm 0.3$ & $6.1 \pm 0.5$ \\
\hline c16:0 & $78.6 \pm 5.8$ & $67.5 \pm 2.4$ & $40.0 \pm 4.4$ & $25.5 \pm 0.8$ & $36.9 \pm 10.9$ & $33.7 \pm 1.7$ & $23.3 \pm 3.6$ & $80.1 \pm 2.5$ & $52.3 \pm 4.1$ & $32.3 \pm 10.2$ \\
\hline $\mathrm{c} 16: 1$ & $117.9 \pm 11.3$ & $90.3 \pm 2.4$ & $52.4 \pm 3.9$ & $39.5 \pm 1.8$ & $50.3 \pm 12.2$ & $47.1 \pm 0.9$ & $37.7 \pm 3.3$ & $113.9 \pm 4.2$ & $67.4 \pm 06.4$ & $42.9 \pm 7.2$ \\
\hline $\mathrm{c} 17: 1$ & $2.1 \pm 0.4$ & $2.0 \pm 0.3$ & $2.1 \pm 0.6$ & $2.7 \pm 0$ & $6.4 \pm 5.3$ & $2.2 \pm 0.1$ & $3.7 \pm 0.7$ & 0 & $0.7 \pm 0.5$ & $1.7 \pm 0.4$ \\
\hline c18:00 & $2.3 \pm 0.1$ & $6.7 \pm 0.5$ & $2.8 \pm 0.2$ & $1.7 \pm 0.1$ & 0 & $1.6 \pm 0.1$ & 0 & $1.9 \pm 0.2$ & $1.6 \pm 0.1$ & 0 \\
\hline $\mathrm{c} 18: 1 \mathrm{n} 9$ & $15.5 \pm 0.2$ & $21.4 \pm 0.4$ & $20.5 \pm 2.4$ & $14 \pm 1.3$ & $8.3 \pm 2.7$ & $14.7 \pm 1.3$ & $10.4 \pm 2.6$ & $10.6 \pm 0.4$ & $12.1 \pm 2.1$ & $12.2 \pm 1.6$ \\
\hline$c 18: 2 n 6$ & $1.9 \pm 0.2$ & $2.0 \pm 0.3$ & $1.3 \pm 0.1$ & $1.3 \pm 0.1$ & $2.0 \pm 0.3$ & $1.2 \pm 0.1$ & $1.1 \pm 0.5$ & $2.4 \pm 0.2$ & $2.5 \pm 0.8$ & $1.4 \pm 0.4$ \\
\hline $\mathrm{c} 18: 3 \mathrm{n} 6$ & $1.4 \pm 0.1$ & 0 & 0 & 0 & 0 & 0 & 0 & $1.6 \pm 0.1$ & $1.1 \pm 0.1$ & 0 \\
\hline $\mathrm{c} 18: 4 \mathrm{n} 3$ & $4.4 \pm 0.1$ & $7.9 \pm 1.4$ & $2.6 \pm 0.3$ & 0 & 0 & 0 & 0 & $3.4 \pm 0.6$ & $1.8 \pm 1.2$ & 0 \\
\hline $\mathrm{c} 20: 3 \mathrm{n} 3$ & $1.2 \pm 0.1$ & 0 & 0 & 0 & 0 & 0 & 0 & $1.1 \pm 0.8$ & 0 & 0 \\
\hline $\mathrm{c} 20: 5 \mathrm{n} 3$ & $29.3 \pm 1.2$ & $30.1 \pm 1.8$ & $22.2 \pm 2.2$ & $24.1 \pm 1.0$ & $21.1 \pm 2.1$ & $20.3 \pm 0.5$ & $23.5 \pm 3.1$ & $26.7 \pm 0.5$ & $20.7 \pm 1.3$ & $17.7 \pm 0.8$ \\
\hline c24:00 & $1.9 \pm 0.2$ & $2.6 \pm 0.1$ & $2.3 \pm 0.3$ & $2.6 \pm 0$ & $2.9 \pm 0.3$ & $2.6 \pm 0$ & $3.1 \pm 0.4$ & $2.9 \pm 0.1$ & $2.3 \pm 0.1$ & $2.4 \pm 0.1$ \\
\hline $\mathrm{c} 22: 6 \mathrm{n} 3$ or $\mathrm{c} 24: 1 \mathrm{n} 9$ & $1.7 \pm 0.1$ & $1.9 \pm 0.1$ & $1.7 \pm 0.2$ & $1.9 \pm 0.1$ & $2.5 \pm 0.1$ & $1.8 \pm 0.1$ & $1.9 \pm 0.3$ & $2.7 \pm 0.1$ & $2.1 \pm 0.1$ & $2.0 \pm 0.1$ \\
\hline$\sum$ Saturated & $94.0 \pm 8.6$ & $87.8 \pm 4.6$ & $50.6 \pm 3.8$ & $34.7 \pm 1.1$ & $48.2 \pm 13.3$ & $43.3 \pm 2.2$ & $31.5 \pm 5.3$ & $98.4 \pm 3.2$ & $64.3 \pm 4.9$ & $40.9 \pm 13.1$ \\
\hline Sig. & $d$ & $d$ & $b, c$ & $a, b$ & $a, b, c$ & $a, b$ & $a$ & $d$ & $\mathrm{c}$ & $a, b$ \\
\hline$\sum$ Monounsaturated & $135.5 \pm 13.4$ & $113.7 \pm 8.0$ & $74.9 \pm 7.0$ & $56.2 \pm 3.2$ & $65.0 \pm 9.2$ & $64.0 \pm 1.8$ & $51.8 \pm 7.6$ & $124.5 \pm 4.6$ & $80.2 \pm 6.4$ & $56.8 \pm 9.9$ \\
\hline Sig. & $\mathrm{e}$ & $\mathrm{d}$ & $\mathrm{b}, \mathrm{c}$ & $a, b$ & $a, b, c$ & $a, b, c$ & $a$ & $\mathrm{~d}, \mathrm{e}$ & c & $a, b$ \\
\hline$\sum$ Polyunsaturated & $38.2 \pm 2.0$ & $40.0 \pm 4.4$ & $26.1 \pm 2.9$ & $25.4 \pm 1.4$ & $23.0 \pm 2.9$ & $21.5 \pm 0.6$ & $24.6 \pm 4.3$ & $35.2 \pm 0.7$ & $26.0 \pm 4.2$ & $19.0 \pm 1.4$ \\
\hline Sig. & b & b & $a$ & $a$ & a & a & a & b & a & $a$ \\
\hline Total Fatty Acids & $269.4 \pm 19.3$ & $243.4 \pm 13.7$ & $154.2 \pm 11.3$ & $118.1 \pm 0.9$ & $138.8 \pm 10.9$ & $130.6 \pm 3.5$ & $110.1 \pm 14.0$ & $260.9 \pm 6.4$ & $172.6 \pm 10.8$ & $118.8 \pm 19.7$ \\
\hline Sig. & $\mathrm{c}$ & $\mathrm{c}$ & $a, b$ & $\mathrm{a}$ & $a, b$ & $a, b$ & $\mathrm{a}$ & c & $\mathrm{b}$ & $\mathrm{a}$ \\
\hline Total Fatty Acids (mg/L media) & 112.0 & 74.2 & 94.2 & 81.2 & 95.6 & 94.4 & 93.5 & 42.1 & 75.2 & 81.1 \\
\hline Sig. & $\mathrm{b}$ & $a, b$ & $a, b$ & $a, b$ & $\mathrm{~b}$ & $\mathrm{~b}$ & $\mathrm{~b}$ & $a, b$ & $a, b$ & $a, b$ \\
\hline
\end{tabular}

Table. 2 Fatty acid composition of $P$. tricornutum grown in ten different media solutions. Letters indicate significant difference determined by a one-way ANOVA comparison with a Ryan-EinotGabriel-Welsch-F post-hoc analysis $(p<0.05))$. Fatty acid data is presented as mean $+/-$ standard deviation ( 3 bioreactors replicates with 3 readings per bioreactor).

\subsubsection{Crude Protein}

The $\mathrm{CHN}$ analysis of microalgae can give an indication of the proportion of protein within the microalgal cell. The crude protein accumulated within $P$. tricornutum showed significant $(p<0.001)$ from 15 to $30 \%$ depending on the media used for growth (Fig. 5 ). The general trend shows that a protein higher concentration in the range of $14.5( \pm 2.1)$ to $28.3( \pm 5.5) \%$ and $20.1( \pm 2.5)$ to $32.4( \pm 2.2) \%$ is accumulated by microalgae in $\mathrm{CW}$ and FW media respectively which have high levels of total inorganic nitrogen (Fig. 2).

This would explain why CW $6 \%$ produced $27.3( \pm 1.5) \%$ and FW $6 \%$ produced 
$32.4( \pm 2.2) \%$ of protein in the microalgae compared to PW $6 \%$ which only produced

$13.7( \pm 2.7)$. No significant difference denoted by the letter A (Table 3 ) was observed between the protein concentration in PW 3 and $6 \%$ digestate compared to the F/2 control. The positive correlation between available nitrogen in growth media and protein accumulation has been well established [59] [60] and could be manipulated depending upon the desired protein composition of microalgae. These results show that it is not just the concentration but also the type of digestate used, which has a significant impact on the composition of $P$. tricornutum crude protein content.

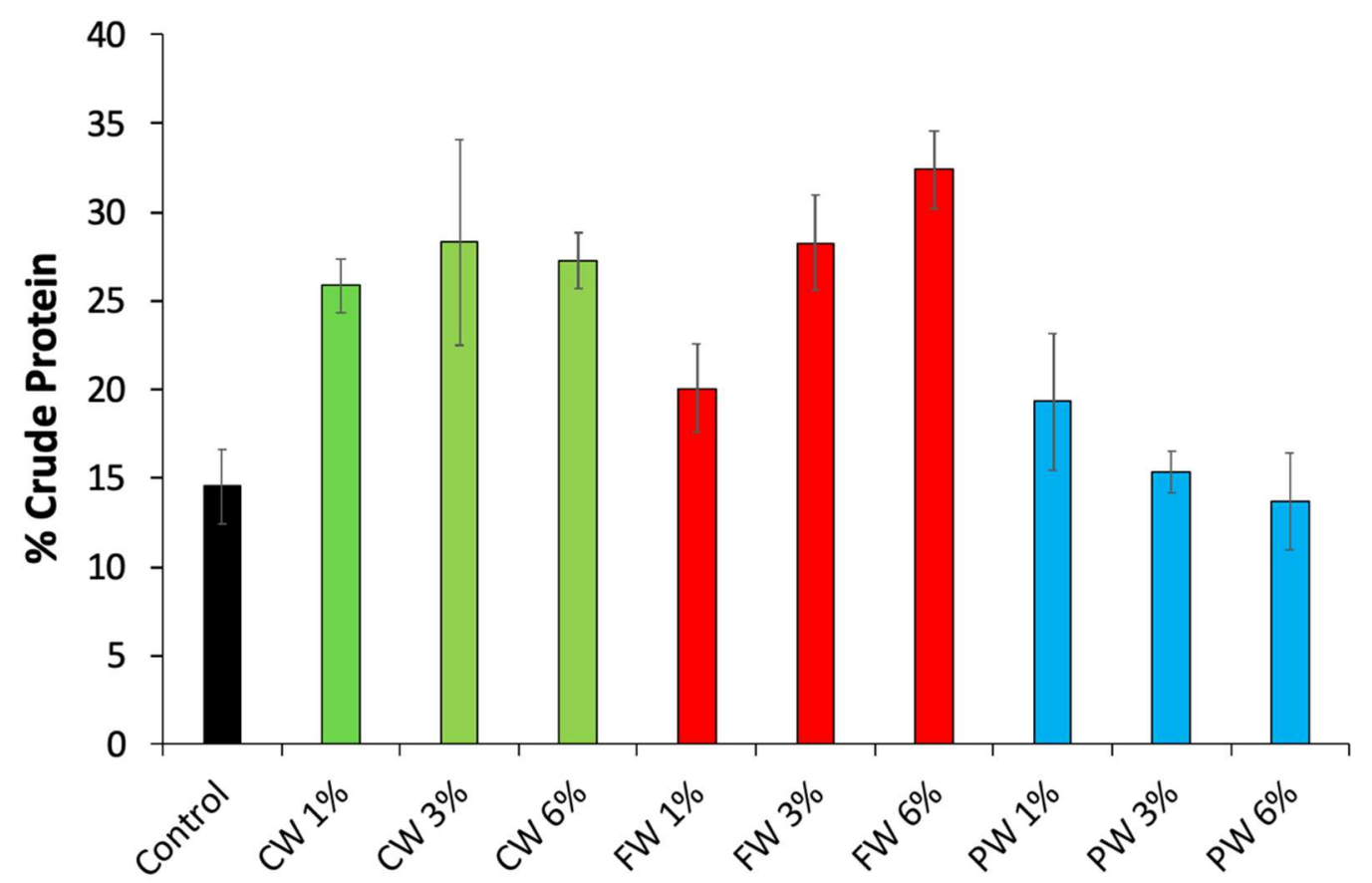

Figure 5. Crude protein calculated for $P$. tricornutum grown in various media. Error bars show standard deviation of three bioreactor replicates. Crude protein data is presented as mean +/standard deviation ( 3 bioreactors replicates with 3 readings per bioreactor).

\begin{tabular}{|c|c|c|c|c|c|c|c|c|c|}
\hline Control & CW 1\% & CW 3\% & CW 6\% & \multicolumn{1}{c}{ FW 1\% } & FW 3\% & FW 6\% & \multicolumn{1}{c|}{ PW 1\% } & PW 3\% & PW 6\% \\
\hline A & B, C, D & C, D & B, C, D & A, B, C & C, D & D & A, B & A & A \\
\hline
\end{tabular}

Table 3: Statistical Data for Figure 5. The letters indicate significant difference between all types of media using one-way ANOVA comparison with a Ryan-Einot-Gabriel-Welsch-F post-hoc analysis $(p<0.05)$.

\subsubsection{Elemental Analysis}


The element data the algae biomass in Fig 6. Fig. 6 a-c shows the elemental analysis of the algal biomass grown on $A D$, whereas Fig. $6 \mathrm{~d}$ shows the elemental profile of the biomass grown on F/2 media. The most noticeable difference in this analysis was in calcium composition between digestate fed microalgae (Fig. 6 a-c) and the F/2 control (Fig. 6d). Algal biomass produced with effluent based nutrients had much higher calcium content than the biomass produced with the synthetic F/2 media (Table 4 , Figure 6). This result is supported by prior work documented in the literature. Synthetic media like $F / 2$ are designed to moderate the cation addition to its seawater base. Unfortunately, effluent based medias do not have this control and the solutes added to seawater base frequently have superfluous cations. This can present an osmotic challenge for cells growing in these cultures. Hayward et al., documented increased calcium uptake by $P$. tricoronatum in response to salinity and conductivity fluctuations similar to those in our effluent based media [61]. Additionally, Ramanan et al., identified algal cell cultures grown in large culture settings directly influence calcium dynamic optimising alkalinity and facilitating photosynthetic efficiency [62]. Likely these mechanisms were in play during our experimental growth period.

\begin{tabular}{|c|c|c|c|c|c|c|c|c|c|c|c|}
\hline Source & Effluent & $\begin{array}{c}\mathrm{Ca} \\
\text { (Digestate) }\end{array}$ & $\begin{array}{l}\text { Ca concentration } \\
\text { in } 5 \mathrm{~L} \text { of } \\
\text { digestate }\end{array}$ & $\begin{array}{l}\text { Ca concentration } \\
\text { in Seawater }\end{array}$ & $\begin{array}{l}\text { Ca concentration } \\
\text { in } 5 \mathrm{~L} \text { of } \\
\text { seawater }\end{array}$ & $\begin{array}{l}\text { Total Ca in } \\
\text { Media }\end{array}$ & $\begin{array}{c}\text { Algae Biomass } \\
\text { Yield } \\
\text { (Dry Wt) }\end{array}$ & $\begin{array}{l}\text { Algal biomass } \\
\quad \text { in } 5 \mathrm{~L}\end{array}$ & $\begin{array}{l}\text { Ca Accumulation } \\
\text { in Algae }\end{array}$ & $\begin{array}{l}\text { Ca Concentration } \\
\text { in Algae }\end{array}$ & $\begin{array}{l}\text { Uptake of Ca } \\
\text { from Media }\end{array}$ \\
\hline Units & $\%$ & $\mathrm{mg} / \mathrm{kg}$ & $\mathrm{mg}$ & $\mathrm{mg} / \mathrm{kg}$ & $\mathrm{mg}$ & $\mathrm{mg}$ & $\mathrm{mg} / \mathrm{L}$ & $\mathrm{g}$ & $\mathrm{mg} / \mathrm{kg}$ & $\mathrm{mg}$ & $\%$ \\
\hline \multirow{3}{*}{ CW } & 1 & 2.96 & 15 & 416 & 2080 & 2095 & 300 & 1.5 & 22302 & 33.45 & 1.60 \\
\hline & 3 & 8.88 & 44 & 416 & 2080 & 2124 & 610 & 3.05 & 57286 & 174.72 & 8.22 \\
\hline & 6 & 17.77 & 89 & 416 & 2080 & 2169 & 700 & 3.5 & 45854 & 160.49 & 7.40 \\
\hline \multirow{3}{*}{ FW } & 1 & 2.96 & 15 & 416 & 2080 & 2095 & 700 & 3.5 & 1680 & 5.88 & 0.28 \\
\hline & 3 & 8.88 & 44 & 416 & 2080 & 2124 & 720 & 3.6 & 44322 & 159.56 & 7.51 \\
\hline & 6 & 17.77 & 89 & 416 & 2080 & 2169 & 850 & 4.25 & 27237 & 115.76 & 5.34 \\
\hline \multirow{3}{*}{ PW } & 1 & 2.96 & 15 & 416 & 2080 & 2095 & 160 & 0.8 & 23554 & 18.84 & 0.90 \\
\hline & 3 & 8.88 & 44 & 416 & 2080 & 2124 & 440 & 2.2 & 42375 & 93.23 & 4.39 \\
\hline & 6 & 17.77 & 89 & 416 & 2080 & 2169 & 690 & 3.45 & 59023 & 203.63 & 9.39 \\
\hline Control & F2 Media & 0 & 0 & 416 & 2080 & 2080 & 420 & 2.1 & 1518 & 3.19 & 0.15 \\
\hline
\end{tabular}

Table 4: Calcium Uptake Data

Much of the organic biomass going into the anaerobic digesters is a rich source of calcium e.g. grass silage and food waste, which explains the source of the metal in the digestate. There has been limited reported research on microalgal elemental 
composition, due to the focus on economically important macromolecules such as lipids and protein. One study [63] grew P. tricornutum in media: F/2, F/2 + Si or Bold's media and reported sodium, potassium and sulphur as the three most abundant elements respectively. This is distinctly different from the composition found in this study which found magnesium, potassium and sodium as the most abundant elements when $P$. tricornutum is grown in F/2 medium. Neither magnesium or potassium were added in the F/2 mix, therefore, these metals have been obtained from the seawater (see supplementary Fig. 1) used to dilute the F/2 mix. There is a range of abiotic (e.g. temperature, light, salinity, nutrients) [64] and biotic factors (e.g. inoculum concentration, species strain) [49] which can effect microalgal elemental composition, which could explain the variation between the two studies. With regards to the three different types of digestate media, the microalgae grown in CW, FW and PW media, showed broadly similar metal composition, despite different feedstocks being fed into the $\mathrm{AD}$ plant. Calcium, magnesium, sodium and phosphorus were the predominant elements present in the microalgae, as shown in Fig. 6. There was a general trend between the concentration of the digestate in the media (Figure 1) and the abundance of elements in the microalgae. There were, however, significant error bars indicating large variation of elemental composition between the three replicate flasks. It is likely that this can be explained by the media $\mathrm{pH}$ and the availability of the metals. High $\mathrm{pH}$ levels can cause metal ions, including calcium, to precipitate from the growth media as salts [65]. The $\mathrm{pH}$ of each medium increased with microalgal growth, therefore the medium $\mathrm{pH}$ had to be balanced to 8.2 at fixed time points throughout the experiment. However, time constraints meant $\mathrm{pH}$ balancing usually extended across two days. This would have meant the availability of some metal ions would vary between replicate flasks depending on the time $\mathrm{pH}$ balancing took place. If the $\mathrm{pH}$ was to be 
maintained at optimal levels, microalgae could be an important tool for the capture and storage of calcium from digestate effluent.
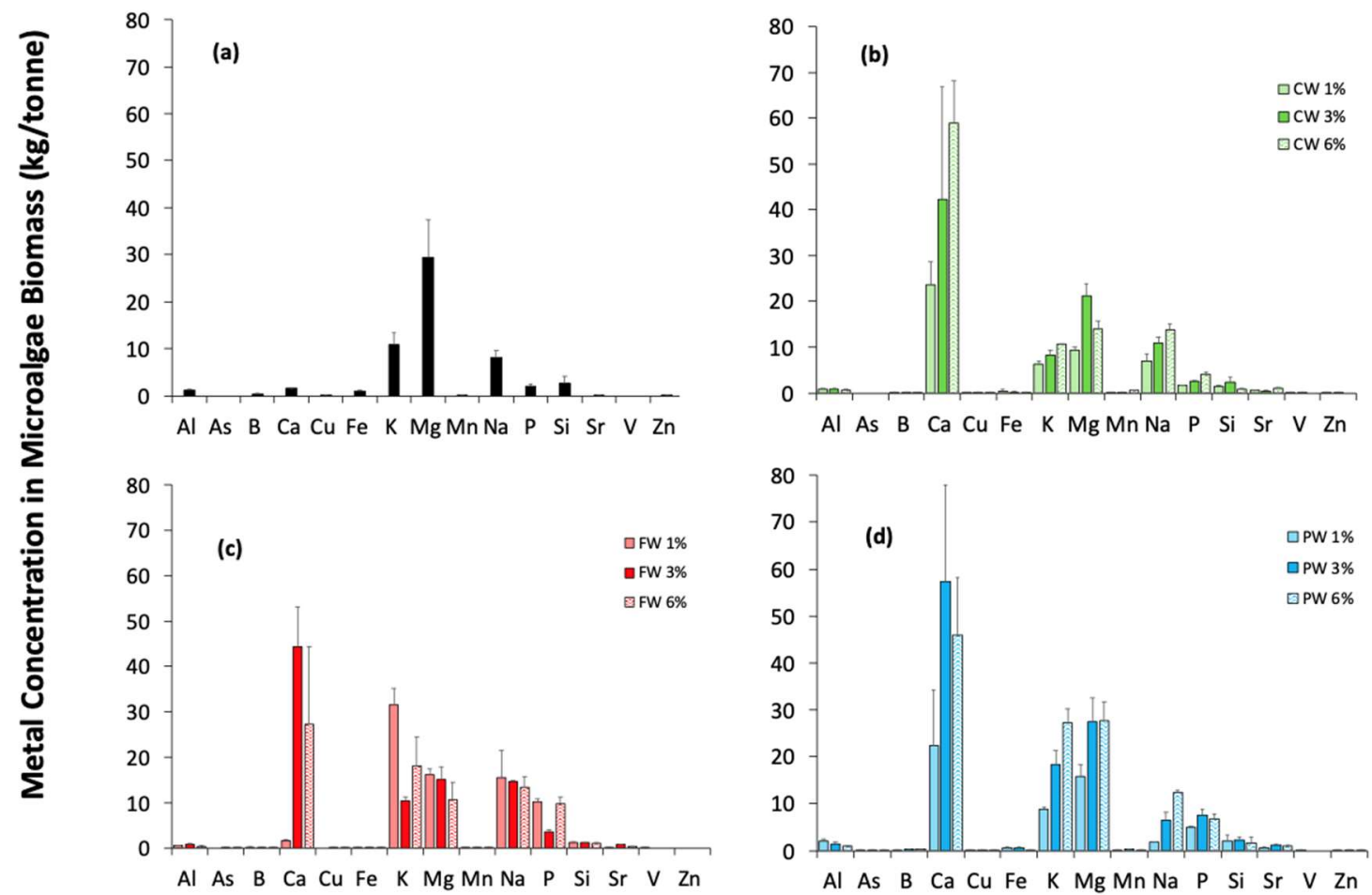

Figure 6. Elemental composition of microalgae grown in different media solutions; a.) microalgae grown in AD Media A $1 \%, 3 \%, 6 \%$ b.) microalgae grown in AD media $B 1 \%, 3 \%, 6$ $\%$ c.) microalgae grown in media AD C $1 \%, 3 \%, 6 \%$ d.) microalgae grown in control F/2 medium. Growth data is presented as mean $+/-$ standard deviation (For each group contained 3 replicate bioreactors, 3 samples were taken per flask, each sample was run in duplicate on the ICP).

\subsection{Potential Applications of Results}

Microalgae have a vast array of applications in industries such as food, cosmetics, biofuels, biofertilisers, pharmaceuticals and aquaculture [66]. Microalgae are not only of use for their biomass, they can remediate nutrients from waste streams including sewage, agriculture, aquaculture and anaerobic digestion [67]. This work assessed the potential of $P$. tricornutum as a source of animal feed and its ability to remediate anaerobic digestion waste. The work looked to compare how $P$. tricornutum grew in 
conventional F/2 media compared with anaerobic digestate as a nutrient source. The results presented in this work show promising signs for $P$. tricornutum to be utilised to bioremediate anaerobic digestate effluent with a promising nutritional chemical profile for animal feeds. This may mean that such nutrient waste streams could be used to make microalgae production more economically viable from an industrial perspective. However, impediments to this may be a reluctance from both industry and the public concerning microalgae grown on waste $A D$ digestate being used for animal feed for human consumption. The digestate effluent in this study was heat treated on site to PASS110 standard and the growth media were also autoclaved, and UV sterilised before the microalgae inoculation to kill any pathogens. Further research is required into possible pathogen transfer and disease transfer between the digestate and the algal biomass before it could be considered for use as an animal feed/food source. Future plans would also have to factor in optimising microalgae growth conditions, to make the process economically viable.

The microalgae compositional data from this study suggests that $P$. tricornutum could be of use to the agriculture/aquaculture sectors as a feedstock. The $P$. tricornutum microalgae grown in this study contained substantial amounts of fatty acids (13-26\% w/w). Lipids, especially those containing unsaturated fatty acids, are an essential part of any livestock diet and these results show that $P$. tricornutum is a rich source of these fatty acids. It could be especially useful for industries which require significant amounts of polyunsaturated fatty acids which are currently obtained from expensive fish oils. The lipid rich microalgae could also be utilised in aquaculture, as a fatty acid source for molluscs, crustaceans and fish [68]. Another substantial proportion of the $P$. tricornutum grown in this study is protein. Using these microalgae as a source of 
dietary protein for livestock could reduce the need for imported sources, such as soy. This would have a knock-on effect of reducing the cost and carbon footprint of food supply chains and increasing food security.

The elemental composition of microalgae can be of importance when using microalgal biomass for animal feed. Minerals in livestock nutrition are involved in many functions including, structural components in body organs, electrolytes in body fluids/tissues, enzyme catalysts and hormones and regulation of cell replication and differentiation [69]. It is important to know the abundance of potentially beneficial micronutrients, as well the presence of any elements which could exceed compliance thresholds [70]. Current EU legislation [71] limits the levels of total arsenic in animal feed to $40 \mathrm{mg} / \mathrm{kg}$, and the microalgae in this experiment would comply with this specification. The most abundant element in the digestate fed microalgae was calcium which was recorded at levels of up to $60,000 \mathrm{mg} / \mathrm{kg}$. Additional calcium is required by many sectors of agriculture for livestock skeletal health, milk production and egg laying [72]. The work presented here shows how microalgae could be used as a sustainable way to recycle the calcium in digestate effluent back into the agricultural food chain.

\section{Conclusion}

This study demonstrated that $P$. tricornutum can be successfully cultivated with anaerobic digestate as the primary nutrient source. Many of the microalgae grown on digestate media had significantly higher levels of calcium and crude protein than the

microalgae grown on synthetic media. $P$. tricornutum contained a range of nutritionally beneficial fatty acids with the total sum of fatty acids making up to a quarter of the dry weight. There are many areas of agriculture which could utilise the nutritional 
compounds within $P$. tricornutum. Growing the microalgae as shown here could increase the sustainability of animal feed production and improve AD remediation while delivering a sustainable economic viability

\section{Acknowledgements}

This research was funded by Centre for Advanced Suitable Energy (CASE)

Competence Centre programme and Industry (Harlequin Ltd, B9 Energy Ltd, Agri. AD)

Project No. A0274 and part funded by Agri-Food Quest (AFQ) Competence Centre

(JMW Farms Ltd) Project No. 11-01- 17-003. Both CASE and AFQ are funded by

Invest NI. We acknowledge the services of ASEP (School of Chemistry and Chemical

Engineering) for ICP-MS analysis and also Emma Healey (nee Gorman) at QML for

her help with Autoanalyzer Analysis. The authors would like to thank Stephen Hull for editorial proofreading of this manuscript.

\section{References}

[1] M. Carmona-Cabello, I.L. Garcia, D. Leiva-Candia, M.P. Dorado, Valorization of food waste based on its composition through the concept of biorefinery, Curr. Opin. Green Sustain. Chem. 14 (2018) 67-79. https://doi.org/10.1016/j.cogsc.2018.06.011.

[2] D. Fangueiro, S. Surgy, I. Fraga, F. Cabral, J. Coutinho, Band application of treated cattle slurry as an alternative to slurry injection: Implications for gaseous emissions, soil quality, and plant growth, Agric. Ecosyst. Environ. 211 (2015) 102-111. https://doi.org/10.1016/j.agee.2015.06.003.

[3] K.M.S. H.L. Foged, X. Flotats, A. Bonmati Blasi, J. Palatsi, A. Magri, Inventory of manure processing activities in Europe, Tech. Rep. No. I Concern. "Manure Process. Act. Eur. to Eur. Comm. Dir. Environ. (2011) 1-139.

[4] J. Edwards, M. Othman, S. Burn, A review of policy drivers and barriers for the use of anaerobic digestion in Europe, the United States and Australia, Renew. Sustain. Energy Rev. 52 (2015) 815-828. https://doi.org/10.1016/j.rser.2015.07.112.

[5] H. Begum, F.M.D. Yusoff, S. Banerjee, H. Khatoon, M. Shariff, Availability and Utilization of Pigments from Microalgae, Crit. Rev. Food Sci. Nutr. 56 (2016) 22092222. https://doi.org/10.1080/10408398.2013.764841.

[6] G. Markou, E. Nerantzis, Microalgae for high-value compounds and biofuels production: A review with focus on cultivation under stress conditions, Biotechnol. Adv. 31 (2013) 1532-1542. https://doi.org/10.1016/j.biotechadv.2013.07.011.

[7] T.D.C. Tarento, D.D. McClure, E. Vasiljevski, A. Schindeler, F. Dehghani, J.M. Kavanagh, Microalgae as a source of vitamin K1, Algal Res. 36 (2018) 77-87. https://doi.org/10.1016/j.algal.2018.10.008.

[8] A. Visca, F. Di Caprio, R. Spinelli, P. Altimari, A. Cicci, G. Iaquaniello, L. Toro, F. 
Pagnanelli, Microalgae cultivation for lipids and carbohydrates production, Chem. Eng. Trans. 57 (2017) 127-132. https://doi.org/10.3303/CET1757022.

[9] M.L. Julius, Carbohydrate Diversity in Microalgae: A Phylogenetically Arranged Presentation, in: IRA. Levine \& Joël Fleurence (Ed.), Microalgae Heal. Dis. Prev., Academic Press, 2018: pp. 133-144. https://doi.org/https://doi.org/10.1016/B978-012-811405-6.00006-2.

[10] S. Bleakley, M. Hayes, Algal Proteins: Extraction, Application, and Challenges Concerning Production, Foods. 6 (2017) 33. https://doi.org/10.3390/foods6050033.

[11] D. Hidalgo, M.L. Mussons, J.M. Martín-Marroquín, F. Corona, Combined Remediation and Protein Production Using Microalgae Growth on Waste Bakery Products, Waste and Biomass Valorization. 9 (2018) 2413-2422. https://doi.org/10.1007/s12649-0180216-y.

[12] J.A. Raven, M. Giordano, Combined Nitrogen, in: M.A. Borowitzka, J. Beardall, J.A. Raven (Eds.), Physiol. Microalgae, Springer International Publishing, Cham, 2016: pp. 143-154. https://doi.org/10.1007/978-3-319-24945-2 7.

[13] E. Uggetti, B. Sialve, E. Latrille, J.P. Steyer, Anaerobic digestate as substrate for microalgae culture: The role of ammonium concentration on the microalgae productivity, Bioresour. Technol. (2014). https://doi.org/10.1016/j.biortech.2013.11.036.

[14] J.A. Alburquerque, C. de la Fuente, A. Ferrer-Costa, L. Carrasco, J. Cegarra, M. Abad, M.P. Bernal, Assessment of the fertiliser potential of digestates from farm and agroindustrial residues, Biomass and Bioenergy. (2012). https://doi.org/10.1016/j.biombioe.2012.02.018.

[15] X. Li, W. Li, J. Zhai, H. Wei, Q. Wang, Effect of ammonium nitrogen on microalgal growth, biochemical composition and photosynthetic performance in mixotrophic cultivation, Bioresour. Technol. 273 (2019) 368-376.

https://doi.org/10.1016/j.biortech.2018.11.042.

[16] F. Monlau, C. Sambusiti, E. Ficara, A. Aboulkas, A. Barakat, H. Carrère, New opportunities for agricultural digestate valorization: Current situation and perspectives, Energy Environ. Sci. 8 (2015) 2600-2621. https://doi.org/10.1039/c5ee01633a.

[17] L. Zuliani, N. Frison, A. Jelic, F. Fatone, D. Bolzonella, M. Ballottari, Microalgae cultivation on anaerobic digestate of municipalwastewater, sewage sludge and agrowaste, Int. J. Mol. Sci. 17 (2016). https://doi.org/10.3390/ijms17101692.

[18] G.Y. Kim, Y.M. Yun, H.S. Shin, J.I. Han, Cultivation of four microalgae species in the effluent of anaerobic digester for biodiesel production, Bioresour. Technol. 224 (2017) 738-742. https://doi.org/10.1016/j.biortech.2016.11.048.

[19] W.J. Bjornsson, R.W. Nicol, K.E. Dickinson, P.J. McGinn, Anaerobic digestates are useful nutrient sources for microalgae cultivation: Functional coupling of energy and biomass production, J. Appl. Phycol. 25 (2013) 1523-1528. https://doi.org/10.1007/s10811-012-9968-0.

[20] M. Massa, S. Buono, A. L. Langellotti, L. Castaldo, A. Martello, A. Paduano, R. Sacchi, $\mathrm{V}$. Fogliano, Evaluation of anaerobic digestates from different feedstocks as growth media for Tetradesmus obliquus, Botryococcus braunii, Phaeodactylum tricornutum and Arthrospira maxima, N. Biotechnol. 36 (2017) 8-16. https://doi.org/10.1016/j.nbt.2016.12.007.

[21] M. Franchino, E. Comino, F. Bona, V.A. Riggio, Growth of three microalgae strains and nutrient removal from an agro-zootechnical digestate, Chemosphere. (2013). https://doi.org/10.1016/j.chemosphere.2013.04.023.

[22] A. Silkina, M.P. Zacharof, G. Hery, T. Nouvel, R.W. Lovitt, Formulation and utilisation of spent anaerobic digestate fluids for the growth and product formation of single cell algal cultures in heterotrophic and autotrophic conditions, Bioresour. Technol. (2017). https://doi.org/10.1016/j.biortech.2017.05.133.

[23] L.M. González-González, E. Eltanahy, P.M. Schenk, Assessing the fertilizing potential of microalgal digestates using the marine diatom Chaetoceros muelleri, Algal Res. (2019). https://doi.org/10.1016/j.algal.2019.101534. 
[24] Z. Yaakob, E. Ali, A. Zainal, M. Mohamad, M.S. Takriff, An overview: Biomolecules from microalgae for animal feed and aquaculture, J. Biol. Res. (2014).

https://doi.org/10.1186/2241-5793-21-6.

[25] K. Skjånes, C. Rebours, P. Lindblad, Potential for green microalgae to produce hydrogen, pharmaceuticals and other high value products in a combined process, Crit. Rev. Biotechnol. (2013). https://doi.org/10.3109/07388551.2012.681625.

[26] M.A. Borowitzka, High-value products from microalgae-their development and commercialisation, J. Appl. Phycol. (2013). https://doi.org/10.1007/s10811-013-99839.

[27] W.A.V. Stiles, D. Styles, S.P. Chapman, S. Esteves, A. Bywater, L. Melville, A. Silkina, I. Lupatsch, C. Fuentes Grünewald, R. Lovitt, T. Chaloner, A. Bull, C. Morris, C.A. Llewellyn, Using microalgae in the circular economy to valorise anaerobic digestate: challenges and opportunities, Bioresour. Technol. 267 (2018) 732-742. https://doi.org/10.1016/j.biortech.2018.07.100.

[28] M. Logan, C. Visvanathan, Management strategies for anaerobic digestate of organic fraction of municipal solid waste: Current status and future prospects, Waste Manag. Res. (2019). https://doi.org/10.1177/0734242X18816793.

[29] M.S. Madeira, C. Cardoso, P.A. Lopes, D. Coelho, C. Afonso, N.M. Bandarra, J.A.M. Prates, Microalgae as feed ingredients for livestock production and meat quality: A review, Livest. Sci. (2017). https://doi.org/10.1016/j.livsci.2017.09.020.

[30] M.P. Caporgno, A. Mathys, Trends in Microalgae Incorporation Into Innovative Food Products With Potential Health Benefits, Front. Nutr. (2018). https://doi.org/10.3389/fnut.2018.00058.

[31] M. Lamminen, A. Halmemies-Beauchet-Filleau, T. Kokkonen, S. Jaakkola, A. Vanhatalo, Different microalgae species as a substitutive protein feed for soya bean meal in grass silage based dairy cow diets, Anim. Feed Sci. Technol. (2019). https://doi.org/10.1016/j.anifeedsci.2018.11.005.

[32] B.A. Altmann, C. Neumann, S. Rothstein, F. Liebert, D. Mörlein, Do dietary soy alternatives lead to pork quality improvements or drawbacks? A look into micro-alga and insect protein in swine diets, Meat Sci. (2019). https://doi.org/10.1016/j.meatsci.2019.03.001.

[33] S.A. Lee, N. Whenham, M.R. Bedford, Review on docosahexaenoic acid in poultry and swine nutrition: Consequence of enriched animal products on performance and health characteristics, Anim. Nutr. (2019). https://doi.org/10.1016/j.aninu.2018.09.001.

[34] J. Flaga, Korytkowski, P. Górka, Z.M. Kowalski, The effect of docosahexaenoic acidrich algae supplementation in milk replacer on performance and selected immune system functions in calves, J. Dairy Sci. (2019). https://doi.org/10.3168/jds.201816189.

[35] Y.B. Wu, L. Li, Z.G. Wen, H.J. Yan, P.L. Yang, J. Tang, M. Xie, S.S. Hou, Dual functions of eicosapentaenoic acid-rich microalgae: Enrichment of yolk with $n-3$ polyunsaturated fatty acids and partial replacement for soybean meal in diet of laying hens, Poult. Sci. (2019). https://doi.org/10.3382/ps/pey372.

[36] M.R. Tredici, L. Rodolfi, N. Biondi, N. Bassi, G. Sampietro, Techno-economic analysis of microalgal biomass production in a 1-ha Green Wall Panel (GWPß) plant, Algal Res. (2016). https://doi.org/10.1016/j.algal.2016.09.005.

[37] M. Rizwan, G. Mujtaba, S.A. Memon, K. Lee, N. Rashid, Exploring the potential of microalgae for new biotechnology applications and beyond: A review, Renew. Sustain. Energy Rev. (2018). https://doi.org/10.1016/j.rser.2018.04.034.

[38] N.N. Zulu, K. Zienkiewicz, K. Vollheyde, I. Feussner, Current trends to comprehend lipid metabolism in diatoms, Prog. Lipid Res. 70 (2018) 1-16. https://doi.org/10.1016/j.plipres.2018.03.001.

[39] I.S. Chronakis, M. Madsen, Algal proteins, in: Handb. Food Proteins, 2011. https://doi.org/10.1016/B978-1-84569-758-7.50014-9.

[40] K. Risberg, H. Cederlund, M. Pell, V. Arthurson, A. Schnürer, Comparative characterization of digestate versus pig slurry and cow manure - Chemical 
composition and effects on soil microbial activity, Waste Manag. (2017).

https://doi.org/10.1016/j.wasman.2016.12.016.

[41] K. Möller, T. Müller, Effects of anaerobic digestion on digestate nutrient availability and crop growth: A review, Eng. Life Sci. (2012).

https://doi.org/10.1002/elsc.201100085.

[42] WRAP, Using quality anaerobic digestate to benefit crops, (2012).

http://www.wrap.org.uk/sites/files/wrap/Using quality digestate to benefit crops.pdf.

[43] S. Boulom, J. Robertson, N. Hamid, Q. Ma, J. Lu, Seasonal changes in lipid, fatty acid, $\alpha$-tocopherol and phytosterol contents of seaweed, Undaria pinnatifida, in the Marlborough Sounds, New Zealand, Food Chem. 161 (2014) 261-269. https://doi.org/10.1016/j.foodchem.2014.04.007.

[44] G. Breuer, W.A.C. Evers, J.H. de Vree, D.M.M. Kleinegris, D.E. Martens, R.H. Wijffels, P.P. Lamers, Analysis of Fatty Acid Content and Composition in Microalgae, J. Vis. Exp. 5 (2013) 1-9. https://doi.org/10.3791/50628.

[45] S.O. Lourenço, E. Barbarino, P.L. Lavín, U.M. Lanfer Marquez, E. Aidar, Distribution of intracellular nitrogen in marine microalgae: Calculation of new nitrogen-to-protein conversion factors, Eur. J. Phycol. (2004). https://doi.org/10.1080/0967026032000157156.

[46] L. Delgadillo-Mirquez, F. Lopes, B. Taidi, D. Pareau, Nitrogen and phosphate removal from wastewater with a mixed microalgae and bacteria culture, Biotechnol. Reports. 11 (2016) 18-26. https://doi.org/10.1016/j.btre.2016.04.003.

[47] A. Pizzera, D. Scaglione, M. Bellucci, F. Marazzi, V. Mezzanotte, K. Parati, E. Ficara, Digestate treatment with algae-bacteria consortia: A field pilot-scale experimentation in a sub-optimal climate area, Bioresour. Technol. (2019). https://doi.org/10.1016/j.biortech.2018.11.067.

[48] S. Cho, N. Lee, S. Park, J. Yu, T.T. Luong, Y.K. Oh, T. Lee, Microalgae cultivation for bioenergy production using wastewaters from a municipal WWTP as nutritional sources, Bioresour. Technol. (2013). https://doi.org/10.1016/j.biortech.2012.12.176.

[49] Y. Su, A. Mennerich, B. Urban, Coupled nutrient removal and biomass production with mixed algal culture: Impact of biotic and abiotic factors, Bioresour. Technol. 118 (2012) 469-476. https://doi.org/10.1016/j.biortech.2012.05.093.

[50] C. González, J. Marciniak, S. Villaverde, P.A. García-Encina, R. Muñoz, Microalgaebased processes for the biodegradation of pretreated piggery wastewaters, Appl. Microbiol. Biotechnol. (2008). https://doi.org/10.1007/s00253-008-1571-6.

[51] E. Sanz-Luque, A. Chamizo-Ampudia, A. Llamas, A. Galvan, E. Fernandez, Understanding nitrate assimilation and its regulation in microalgae, Front. Plant Sci. (2015). https://doi.org/10.3389/fpls.2015.00899.

[52] N. Brown, A. Shilton, Luxury uptake of phosphorus by microalgae in waste stabilisation ponds: Current understanding and future direction, Rev. Environ. Sci. Biotechnol. 13 (2014) 321-328. https://doi.org/10.1007/s11157-014-9337-3.

[53] K.W. Chew, S.R. Chia, P.L. Show, T.C. Ling, S.S. Arya, J.S. Chang, Food waste compost as an organic nutrient source for the cultivation of Chlorella vulgaris, Bioresour. Technol. 267 (2018) 356-362.

https://doi.org/10.1016/j.biortech.2018.07.069.

[54] H. Wu, T. Li, G. Wang, S. Dai, H. He, W. Xiang, A comparative analysis of fatty acid composition and fucoxanthin content in six Phaeodactylum tricornutum strains from different origins *, 34 (2015) 391-398.

[55] D. Swanson, R. Block, S.A. Mousa, Omega-3 fatty acids EPA and DHA: health benefits throughout life, Adv. Nutr. An .... (2012) 1-7. https://doi.org/10.3945/an.111.000893.Omega-3.

[56] D.J.A. Jenkins, J.L. Sievenpiper, D. Pauly, U.R. Sumaila, C.W.C. Kendall, F.M. Mowat, Are dietary recommendations for the use of fish oils sustainable?, Can. Med. Assoc. J. 180 (2009) 633 LP - 637.

[57] K.I. Reitan, J.R. Rainuzzo, Y. Olsen, Effect of Nutrient Limitation on Fatty-Acid and Lipid-Content of Marine Microalgae, J. Phycol. 30 (1994) 972-979. 
https://doi.org/10.1111/j.0022-3646.1994.00972.x.

[58] Y. Li, X. Fei, X. Deng, Novel molecular insights into nitrogen starvation-induced triacylglycerols accumulation revealed by differential gene expression analysis in green algae Micractinium pusillum, Biomass and Bioenergy. 42 (2012) 199-211. https://doi.org/10.1016/j.biombioe.2012.03.010.

[59] M. Piorreck, K.H. Baasch, P. Pohl, Biomass production, total protein, chlorophylls, lipids and fatty acids of freshwater green and blue-green algae under different nitrogen regimes, Phytochemistry. 23 (1984) 207-216. https://doi.org/10.1016/S00319422(00)80304-0.

[60] D. Simionato, M.A. Block, N. La Rocca, J. Jouhet, E. Maréchal, G. Finazzi, T. Morosinotto, The response of Nannochloropsis gaditana to nitrogen starvation includes de novo biosynthesis of triacylglycerols, a decrease of chloroplast galactolipids, and reorganization of the photosynthetic apparatus, Eukaryot. Cell. 12 (2013) 665-676. https://doi.org/10.1128/EC.00363-12.

[61] J. Hayward, Studies on the growth of phaeodactylum tricornutum VI. The relationship to sodium, potassium, calcium and magnesium, J. Mar. Biol. Assoc. United Kingdom. (1970). https://doi.org/10.1017/S0025315400004549.

[62] R. Ramanan, K. Kannan, A. Deshkar, R. Yadav, T. Chakrabarti, Enhanced algal CO2 sequestration through calcite deposition by Chlorella sp. and Spirulina platensis in a mini-raceway pond, Bioresour. Technol. (2010). https://doi.org/10.1016/j.biortech.2009.10.061.

[63] S.M. Tibbetts, J.E. Milley, S.P. Lall, Chemical composition and nutritional properties of freshwater and marine microalgal biomass cultured in photobioreactors, J. Appl. Phycol. 27 (2015) 1109-1119. https://doi.org/10.1007/s10811-014-0428-x.

[64] C. Paliwal, M. Mitra, K. Bhayani, S.V.V. Bharadwaj, T. Ghosh, S. Dubey, S. Mishra, Abiotic stresses as tools for metabolites in microalgae, Bioresour. Technol. 244 (2017) 1216-1226. https://doi.org/10.1016/j.biortech.2017.05.058.

[65] F. lasimone, A. Panico, V. De Felice, F. Fantasma, M. lorizzi, F. Pirozzi, Effect of light intensity and nutrients supply on microalgae cultivated in urban wastewater: Biomass production, lipids accumulation and settleability characteristics, J. Environ. Manage. 223 (2018) 1078-1085. https://doi.org/10.1016/j.jenvman.2018.07.024.

[66] I. Priyadarshani, B. Rath, Commercial and industrial applications of micro algae - A review, J. Algal Biomass Util. 3 (2012) 89-100. https://doi.org/10.1016/j.(73).

[67] A. Guldhe, S. Kumari, L. Ramanna, P. Ramsundar, P. Singh, I. Rawat, F. Bux, Prospects, recent advancements and challenges of different wastewater streams for microalgal cultivation, J. Environ. Manage. 203 (2017) 299-315. https://doi.org/10.1016/j.jenvman.2017.08.012.

[68] M.R. Brown, S.W. Jeffrey, J.K. Volkman, G.A. Dunstan, Nutritional properties of microalgae for mariculture, Aquaculture. 151 (1997) 315-331. https://doi.org/https://doi.org/10.1016/S0044-8486(96)01501-3.

[69] E.J. Underwood, N.F. Suttle, The Mineral Nutrition of Livestock, CABI Pub., 1999.

[70] P.A. and A.M. L. Campanella, G. Crescentini, Determination of macrominerals and trace elements in the alga Spirulina platensis, Analusis. (1998) 210-214. https://doi.org/10.1051/analusis.

[71] E. Commission, Directive 2002/32/EC of the European Parliament and of the Council of 7 May 2002 on undesirable substances in animal feed, Off. J. Eur. Comm. 140 (2002) 10-21.

[72] P. McDonald, Animal Nutrition, Prentice Hall, 2002. 